\title{
МЕТОДИКИ ОБУЧЕНИЯ ИГРЕ НА ФОРТЕПИАНО: ЗАРУБЕЖНЫЙ ОПЫТ
}

\section{PIANO TEACHING APPROACHES: FOREIGN EXPERIENCE}

Li Jingbo

Summary: The article is devoted to the problems of teaching methods in playing the piano in foreign countries. The purpose of the article is to consider the main methodological approaches in modern musical pedagogy (in some foreign countries). The objectives of the article are consistent with the goal and consist in analyzing the scientific literature on the research topic, as well as in summarizing the approaches and practices of teaching piano in foreign countries while moving away from the traditional teaching system. The methodology of the article is based on a systematic approach and includes a group of general scientific methods (analysis, synthesis, deduction, induction), as well as a group of special methods: content analysis of scientific literature on the research topic; as well as elements of descriptive analysis. Based on the research, the author of the article concludes that the dominant in modern foreign countries teaching methods of playing the piano are (in addition to the traditional method) an integrative interdisciplinary approach and cultural analysis of music (China); simplified and group method (USA), as well as online formats with a predominance of proprietary private methods (France and Germany). The author considers the humanization of music education: accessibility, understanding of the cultural specifics of students, and also taking into account individual educational needs as a general trend in modern musical pedagogy of teaching piano.

Keywords: musical pedagogy, musical education, traditional method, piano, foreign experience in teaching.

A ктуальность темы исследования обусловлена тем, что между современным и традиционным музыкальным образованием существуют различия, которые проявляются в образовательной цели, концепции, ориентированной на учащихся, отношении преподавателя к обучаемому, содержанию, методике преподавания и процессу обучения [1, с.173].

В целом, теория современного музыкального образования в развитых странах воспринимается как новая система методов обучения игре на музыкальных инструментах, фокусируясь на проблеме мотивации и личностного роста будущих исполнителей [1, с.174].

Тем не менее, в настоящее время в современном преподавании фортепиано существует много проблем, что проявляется в следующем: преподавательский состав относительно слаб, базовые различия велики, а общепринятый метод преподавания относительно консер-

\author{
Ли Цзинбо \\ ассистент-стажер, ФГБОУ ВО «Российская академия \\ музыки имени Гнесиных» \\ legendbobo1202@qq.com
}

Аннотация: Статья посвящена проблематике методов обучения игре на фортепиано в зарубежных странах. Цель статьи заключается в рассмотрении основных методологических подходов и методов в современной музыкальной педагогике (на примере некоторых зарубежных стран). Задачи статьи согласуются с поставленной целью и состоят в анализе научной литературы по теме исследования, а также в суммировании подходов и практик преподавания игры на фортепиано в зарубежных странах в условиях отхода от традиционной системы обучения. Методология статьи основана на системном подходе и включает в себя группу общенаучных методов (анализ, синтез, дедукция, индукция), а также группу специальных методов: контент-анализ научной литературы по теме исследования; сопоставительный анализ, а также элементы описательного анализа. На основании проведенного исследования, автор статьи приходит к выводу о том, что доминирующими в современных зарубежных странах методиками обучения игре на фортепиано являются (помимо традиционного метода) интегративный междисциплинарный подход и культурологический анализ музыки (Китай); упрощенный и групповой метод (США), а также онлайн-форматы с преобладанием авторских частных методик (Франция и Германия). Общей тенденцией в современной музыкальной педагогике обучения игре на фортепиано автор статьи считает гуманизацию музыкального образования: доступность, понимание культурной специфики обучаемых, а также учет индивидуальных образовательных потребностей.

Ключевые слова: музыкальная педагогика, музыкальное образование, традиционный метод, фортепиано, зарубежный опыт преподавания.

вативен. В целях совершенствования практики преподавания игры на фортепиано необходимо рассмотреть те методы, который используются в развитых странах [2, c.59].

Анализ научной литературы по теме исследования позволяет говорить о том, что строгие традиции преподавания фортепиано оставались укоренившимися в течение нескольких поколений. Доминирующее влияние Муцио Клементи (1752-1832), первого композитора-педагога по фортепиано, привело к возникновению классических принципов обучения и строгих систем преподавания, примером чего являются крайне сложные упражнения Ханона «Пианист-виртуоз» [4, с.26]. Такие практики, которые многие современные исследователи считают абсурдными и даже оскорбительными для современных студентов [3, с.850], существуют сегодня на всех уровнях музыкального образования по фортепиано в высших учебных музыкальных заведениях, подверга- 
ясь постоянной критике современных педагогов.

В частности, в своей книге У.П. Макфарланд критически рассматривает два столетия методов обучения и призывает преподавателей покончить с традициями, которые разъединяют умственные и творческие навыки [6, с.110]. В условиях принципиально нового сознания учеников и новых технологий, музыкальная педагогика в сфере обучения игре на фортепиано не должна оставаться в том же состоянии, что и столетия назад. Такого мнения придерживаются многие современные педагоги развитых стран. Например, в своей статье А. Фиренцелли доказывает, что учебный процесс во многих ситуациях сводится к простому чтению нот, при этом на практике редуцируется самый важный аспект - сама музыка, поскольку обучение ведется с упором только на механическое повторение более сложных технических приемов [4, с.26]. В своей работе А. Фиренцелли также предоставляет разнообразные решения и возможности, иллюстрируемые конкретными примерами обучения, основанными на его собственном педагогическом опыте.

В целом, современная зарубежная музыкальная педагогика предлагает множество методик обучения игре на фортепиано (помимо классического подхода).

По сравнению с традиционным методом, который включает обучение сольфеджио, тренировке ритма и воспроизведению музыки с нотами и упражнениями, во многих европейских странах используется упрощенная методика (онлайн-курсы и обучающее видео) [1, с.173]. В большинстве таких занятий музыка состоит из аккордов и последовательностей аккордов: они следуют друг за другом в соответствии с определенной логикой, которую может выучить большинство людей, что относится в том числе и к импровизации.

В данной гамме фортепиано (например, в мажоре ре мажор) каждая нота и каждый аккорд, построенные на этой ноте, имеют точную функцию. Например, в до мажоре аккорд С имеет тоническую функцию (первая степень шкалы диатонической шкалы). Нота G является доминирующей степенью До мажор (доминирующий седьмой аккорд).

Затем есть субдоминантный аккорд, четвертая тональная степень диатонической шкалы: До мажор - аккорд F. Данные три аккорда: тонический, доминантный и субдоминантный позволяют достаточно быстро научиться импровизировать. Упрощенный метод обучения используется, в частности, для тех категорий учеников, которые не относятся к профессиональным музыкантам, а также успешно применяется в качестве физиотерапии $[8$, c.16]. Такой упрощенный подход к обучению игре на фортепиано используется в самых различных форматах: обучение в малых группах (групповой метод); онлайнкурсы игры на фортепиано; интерактивные учебные пособия по обучению игре на фортепиано и т.п. Такой интерактивный подход к обучению применяется в основном в странах Западной Европы (Франция и Германия) [4, C.27].

Некоторые исследователи также предлагают конкретные варианты отхода от традиций индивидуальных занятий в процессе обучения игре на фортепиано. Так, в своей работе американский исследователь Б. Тесимер рассматривает историю создания методологии группового обучения игре на фортепиано и использование такого направления в музыкальных образовательных учреждениях США [8, с.17]. Автор также полагает, что групповое обучение игре на фортепиано, как правило, призвано обеспечить основу для функциональных навыков игры на инструменте в дополнение к художественным навыкам. К функциональным навыкам относятся такие аспекты, как чтение нот с листа, транспозиция, аккорд, гармония, импровизация, ансамблевое сопровождение, аккомпанемент, анализ и чтение партитуры [8, c.22]. Интересно, что групповой метод обучения весьма широко применяется в США не только для подготовки будущих исполнителей- профессиональных музыкантов, но также в качестве физиотерапии для пожилых людей, что значительно расширяет поле исследования методики преподавания игры на фортепиано. Данные тезисы подтверждаются в работах других авторов.

Так, в междисциплинарном эмпирическом исследовании Дж. Бугос [3, с.852] была проведена оценка влияния групповой игры на фортепиано на исполнительные функции и психосоциальные результаты у здоровых пожилых людей (возрастная группа 60-80 лет). В этом кластерном контролируемом исследовании была проведена первоначальная трехчасовая оценка стандартизированных когнитивных и психосоциальных эффектов группового обучения игре на фортепиано. Участники были разделены по возрасту, уровню образования и оценке интеллекта, а затем были случайным образом распределены по одной из трех групп: групповое обучение игре на фортепиано, обучение компьютерным технологиям и контрольная группа без терапии. Результаты повторных измерений показали значительное улучшение по производительности мышления и устной речи в группе обучения игре на фортепиано по сравнению с контрольной группой [3, с.853].

Групповая методика обучения игре на фортепиано используется также для категории людей с особыми образовательными потребностями. Так, в работе Е. Тагаревой рассматривается интерактивная составляющая метода. Автор считает, что с точки зрения музыкальной педагогики фортепианное образование направлено на достижение художественных и эстетических результа- 
тов [7, с.40]. В свете современной музыкальной педагогики обучение фортепиано должно рассматриваться как сложный интерактивный процесс, который поддерживает развитие личности людей с особыми образовательными потребностями и позволяет решать многочисленные проблемы, связанные с педагогикой и терапией. Через универсальный язык искусства (в данном случае - музыки) происходит невербальное творческое взаимодействие между учителем и учеником, которое способствует разработке комплексных методов преодоления психических, сенсорных, коммуникативных и физических трудностей [7, с.39]. Групповое обучение игре на фортепиано людей с особыми образовательными потребностями - это активная познавательная, творческая, эмоциональная и двигательная деятельность, где устанавливаются компенсаторные механизмы коррекции и балансирования инвалидности, расстройств, дефицита внимания и т.п. - одна из основных целей художественной педагогики. При этом, в процессе обучения в группе, конечная цель внешней поддержки ученика преподавателем состоит в том, чтобы ученик мобилизовал свои внутренние умственные, эмоциональные, интеллектуальные способности и физические силы, научившись самостоятельно и творчески справляться с возникающими трудностями - на основе своих неповрежденных чувств и методов, предлагаемых учителем, которые должны быть совместно разработаны и самостоятельно применены. Развитие компенсаторных механизмов - это не стихийный, а полностью системный процесс, где педагог играет первостепенную роль, педагог приобретает определенные качества - профессиональные знания и навыки, новаторский дух и глубокое понимание особенностей и трудностей своих учеников с особыми образовательными потребностями. Результаты такого обучения, имеющие несколько аспектов, являются комплексными: улучшение психоэмоционального состояния учащегося, восторг от достижений, готовность активно участвовать в творческой деятельности, повышение самооценки и самоуважения, преодоление неопределенности и социальной адаптации. Как показал опыт зарубежных музыкальных учреждений, обучение игре на фортепиано оказалось полезным для большого числа слепых и слабовидящих, слабослышащих, студентов с нарушениями умственной, речевой и двигательной активности. Создание и совершенствование методологий для студентов с особыми образовательными потребностями является вкладом в педагогическую науку и реализацией гуманистических идеалов на практике.

С позиций формирования эстетического взгляда на мир и гуманизации музыкального образования, интересным и ценным представляется подход к обучению игре на фортепиано в китайских музыкальных учреждениях разного уровня. В частности, в 2000 году в Пекине был проведен «Симпозиум по реформе преподавания фортепиано в университетах», а в 2004 году был создан академический комитет по фортепиано, с помощью которого Академия преподавания фортепиано при Китайской музыкальной ассоциации активно развивает многие академические направления деятельности [10, c.2]. Всеобъемлющая система игры на фортепиано в китайских музыкальных образовательных учреждениях включает в себя музыкальное сопровождение, а урок истории фортепиано является теоретическим руководством. При этом преподавание фортепиано должно быть направлено на изучение музыкальной культуры фортепиано. Следует отметить, что в китайской опыте заметет отход от традиционной системы обучения, согласно требованиям и потребностям образования XXI века. Так, в соответствии с теорией мульти-интеллекта Гарднера, преподаватель Пекинской академии музыки Ван Йихонг создал новый, коллективный курс фортепиано, применяя теорию мульти-интеллекта в коллективном курсе фортепиано в обычных колледжах, что принесло новые исследовательские взгляды и открытия [9, с.94]. В настоящее время система преподавания цифрового фортепиано является продуктом синтеза классической системы преподавания с современной наукой и технологией. Такая новая концепция преподавания и обучения игре на фортепиано в китайских музыкальных учебных заведениях органично сочетается со знанием других предметов и дает кумулятивный эффект в рамках межпредметной интеграции. интеграция между различными субъектами [9, с.95].

В китайской концепции обучения игре на фортепиано преобладает культурологический подход. Так, в своей статье Х. Хонг и Т. Тибодо отмечают, что «Восток и Запад стали музыкально переплетенными благодаря значительному участию азиатских или «восточных» людей в западной классической музыке, несмотря на глубоко различающиеся трактовки гармонии и ритма в традиционной азиатской музыке» [5, с.25]. При этом западные исследователи отмечали, что «студенты из разных культур могут подходить ко всему музыкальному опыту с разных точек зрения» [9, с.94]. Однако, по мнению китайских преподавателей фортепиано, такое различие, если оно существует, потребовало бы гораздо более детального рассмотрения не только выбора в учебных материалах по музыке, но и действий, стратегий и целей для изучения музыки» [5, p. 27]. Современная китайская педагогическая доктрина обучения игры на фортепиано основана на том, что учителя должны осознавать культурные различия в обучении, особенно в подходе к западной классической музыке: язык, эмоциональные реакции и т. д., чтобы эффективно преподавать в многонациональных группах студентов.

Таким образом, можно сделать вывод, что современный зарубежный опыт состоит в широком применении целевого методологического подхода к обучению игры на фортепиано. По мнению большинства зарубежных ис- 
следователей, в современной музыкальной педагогике «нет правильных или неправильных методов, все зависит от конечной цели» [6, с.104]. Данный подход охватывает широкий спектр методик, от классических до гибридных. В частности, достаточно широко применяются специальные методы для разных музыкальных жанров: от классической музыки до джаза, блюза, эстрады и т.п.

В силу всего сказанного, перспективным направлением последующих исследований представляется сравнительный анализ западной и восточной музыкальной педагогики в свете отхода от традиционной модели обучения.

\section{ЛИТЕРАТУРА}

1. Карчина А.Ф. Методы обучения игре на фортепиано // Царскосельские чтения. 2016. № 3. - С. 172-175.

2. Куровская И.Р., Макарова Е.В. Формирование технических навыков игры на фортепиано: традиции школы г. Нейгауза в ялтинских образовательных учреждениях // Таврический научный обозреватель. 2017. № 4. - С.58-62.

3. Bugos J. Piano Training on Executive Functions and Psychosocial Outcomes In Older Adults. Innovation in Aging. 2018. Volume 2. - P. 849 - 856. D0l: 10.1093/ geroni/igy023.3166

4. Firrincieli. Modern piano teaching and practice methods: Considerations and comparison with language learning. Music World. 2015. Vol.7. - P. 25-34.

5. Huang H., Thibodeaux T. Teaching Piano in China: Building Transcultural and Transhistorical Bridges through Music Education. International Research in Higher Education. 2016. № 1. - P. 25-33.

6. McFarland W.P. The Tyranny of Tradition in Piano Teaching: A Critical History from Clementi to the Present. 2019. - 261 p.

7. Tagareva E. Compensatory mechanisms establishment in piano training of persons with special educational needs - approach, methods, results. Knowledge International Journal. 2018. Vol. 28. No 3. - P. 39-45. D0l: 10.35120/kij28031035EISBN: 2545-4439

8. Tecimer B. Group Piano Training in the United States of America. Music World. 2020. Vol. 3. - P. 15-24.

9. Wang C. Professional Piano Education in Chinese Piano Music Culture. International Educational Studies. 2014. Vol.3. - P. 93-95.

10. Yang Feiyue. Piano teaching system for children launched in Beijing. China Daily. 2015. Vol.3. - P.1-7.

(c) Ли Цзинбо (legendbobo1202@qq.com).

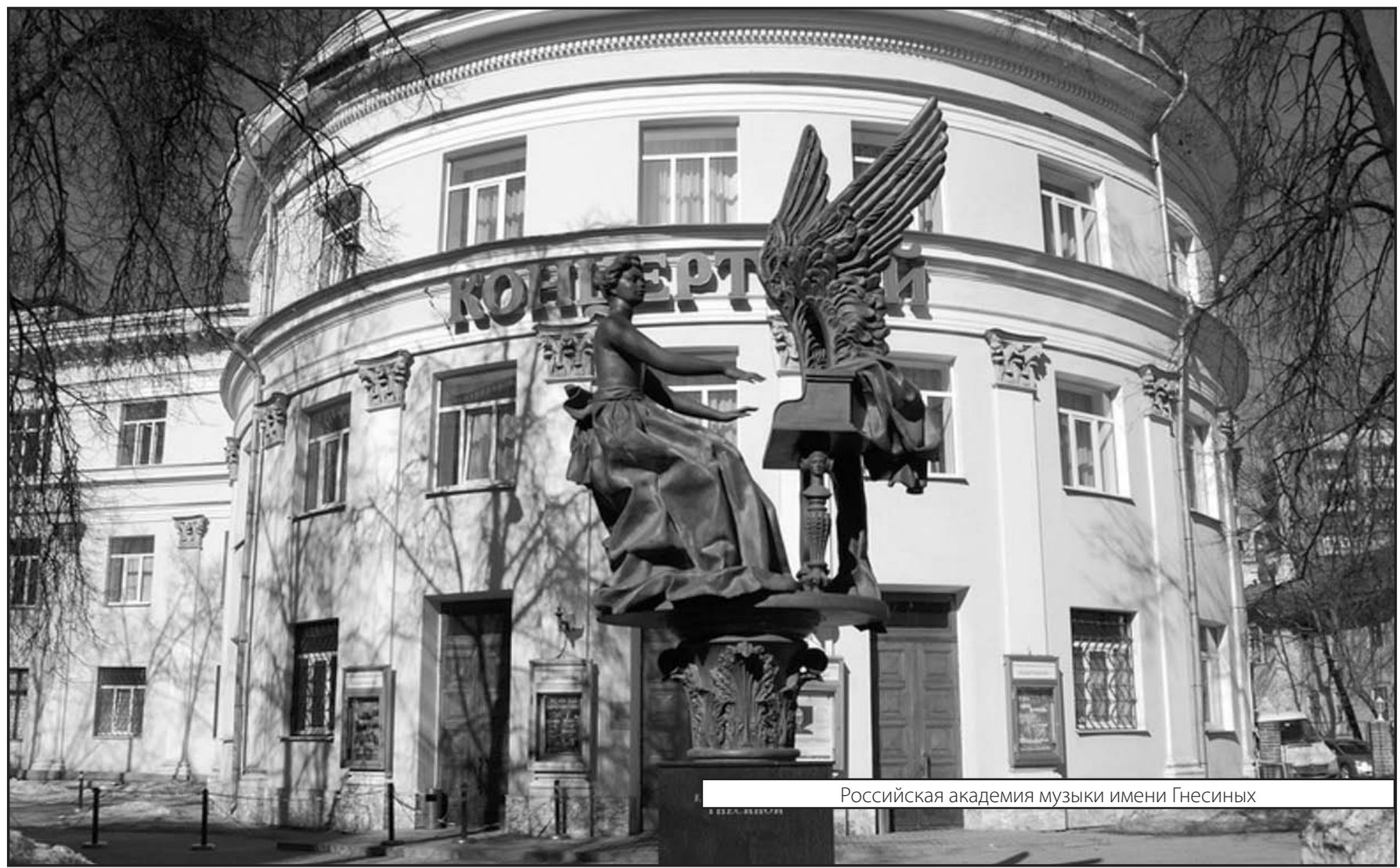

